\title{
Changes in Jasmonates of Mangoes during Development and Storage after Varying Harvest Times
}

\author{
Satoru Kondo ${ }^{1}$ and Futoshi Yazama \\ Graduate School of Applied Biosciences, Hiroshima Prefectural University, Shobara, Hiroshima 727- \\ 0023, Japan
}

\author{
Kasinee Sungcome and Sirichai Kanlayanarat \\ Division of Postharvest Technology, King Mongkut's University of Technology Thonburi, Bangkok 10140, \\ Thailand
}

\author{
Hideharu Seto \\ RIKEN, The Institute of Physical and Chemical Research, Wako, Saitama 351-0198, Japan
}

ADDITIONAL INDEX WORDS. 1-aminocyclopropane-1-carboxylic acid, jasmonic acid, Mangifera indica, methyl jasmonate, senescence

\begin{abstract}
Jasmonic acid (JA) and methyl jasmonate (MeJA) were quantified in the skin, pulp, and seeds of 'Nam Dok Mai' and 'Nang Klangwan' mangoes (Mangifera indica L.). JA showed similar changes during development in both cultivars of fruit. JA concentrations were high in the early growth stages of skin and pulp development, decreased with days after full bloom (DAFB), and then increased again during ripening. JA concentrations in the skin were higher than those in the pulp. 1-aminocyclopropane-1-carboxylic acid (ACC) concentrations in the skin and pulp of both cultivars increased toward harvest. Differing with JA, ACC concentrations in the pulp were high compared with the skin. This fact suggests that although JA and ACC are associated with the ripening of mangoes, they may play different roles. JA concentrations in the seeds of both cultivars decreased toward harvest, possibly suggesting a lack of dormancy in mango seeds. Changes in jasmonates during storage were also examined. JA content in the skin and pulp increased in stored fruit. In addition, the increase in JA content was largest in fruit that lost the most fresh weight. This suggests that JA accumulation that occurs during fruit senescence is associated with moisture loss.
\end{abstract}

Since jasmonates [Jasmonic acid (JA) and methyl jasmonate (MeJA)] were discovered in jasmines (Jasminum grandiforum L.) (Ueda, 1991), much useful research has followed. These include the physiological effects of jasmonates and their metabolites on the induction of pigmentation and flavonoid gene expression in petunia corollas (Petunia hybrida) (Tamari et al., 1995), the stimulation of potato (Solanum tuberosum L.) tuberization (Koda et al., 1988), and the promotion of bulb development in onion plants (Allium cepa $\mathrm{L}$.) (Nojiri et al., 1992). The effects of jasmonates on fruit development have also been investigated. We reported that JA stimulated callus formation on apple [Malus sylvestris (L.) Mill. var.domestica(Borkh.) Mansf.] pulp discs (Kondo et al., 2001a) and promoted anthocyanin accumulation in apple skin (Kondo et al., 2001b). However, in sweet cherries (Prunus avium L.) (Kondo et al., 2002a) and grape berries (Vitis spp.) (Kondo and Fukuda, 2001), JAdid not affect anthocyanin formation. These facts suggest that the role of jasmonates vary among fruits. Exogenous treatment of $n$-propyldihydrojasmonate (PDJ), which is a jasmonate derivative, to peaches retarded physiological fruit drop and increased the rate of fruit set. However, the treatment to Japanese pears promoted flower and fruit thinning (Takeuchi and Kamuro, 1997). It is clear that the effects of jasmonates such as PDJ differed among fruits. As for the practical application of jasmonates in fruit cultivation, the function of endogenous jasmonates during development in each fruit should be explored.

Mangoes are popular around the world because they are both sweet and nutritious. The research on the function of ethylene in

Received for publication 9 Oct. 2003. Accepted for publication 6 Nov. 2003. We thank Nippon Zeon Co., Ltd., Tokyo, for providing JA and MeJA.

1To whom reprint requests should be addressed; e-mail s-kondo@bio.hiroshimapu.ac.jp. mango fruit, which is climacteric, is extensive. Increasing ethylene during the late development stage influenced the ripening and storability of mangoes (Mitra and Baldwin, 2001). Although jasmonates may be associated with fruit development of mangoes, research has yet to begin. There are few studies on the role of jasmonates during mango fruit development. Mangoes harvested later in development may be sold at nearby markets, but mangoes stored or shipped to distant markets should be harvested while still green and firm (Mitra and Baldwin, 2001). Some kinds of mango have been harvested and consumed as immature fruit. The concurrence between the increase of jasmonates and softening in apple fruit (Kondo et al., 2000) suggests that jasmonates are associated with the ripening and/or senescence of fruit. However, jasmonate concentrations in apple fruit that were high at the immature stage decreased during maturation, then increased again at the ripening stage (Kondo et al., 2000). These facts suggest that the roles of jasmonates differ with fruit development stage. The changes of ethylene production during storage in harvested apples differed with the harvest times (Blanpied and Blak, 1976). Therefore, jasmonate content in harvested mangoes may differ according to the harvest times and may affect storage life. The degree of moisture loss significantly influences the storability of mango fruit. Coatings and waxes on mango skin are useful in extending the shelf life (Mitra and Baldwin, 2001). Although moisture loss lowers the quality in stored fruit (Tsuda et al., 1999), the effect of moisture loss on jasmonates is yet unknown. In this study, changes of endogenous jasmonates in mango fruit were investigated to clarify the role of jasmonates in fruit development. The endogenous jasmonates in fruit stored at different relative humidities after varying harvest times were also examined. 


\section{Materials and Methods}

Plant materials. Ten randomly selected 19- to 20-year-old 'Nam Dok Mai' (early harvest) and 'Nang Klangwan'(late-harvest) mango trees (Mangifera indica L.) from a commercial orchard in Ratchaburi province (lat. $13^{\circ} \mathrm{N}$ ), Thailand were used for this experiment in 2001 and 2002. Fifteen to 30 fruit were collected (depending on fruit development stage) from $14 \mathrm{~d}$ after full bloom (DAFB) until harvest (98 DAFB in 'Nam Dok Mai' and 112 DAFB in 'Nang Klangwan') at $14 \mathrm{~d}$ intervals for analyses of jasmonates, $\mathrm{CO}_{2}$, and 1-aminocyclopropane-1-carboxylic acid (ACC). After collection, the skin, pulp, and seed samples were immediately frozen in liquid $\mathrm{N}_{2}$ and lyophilized. Skin color was measured at two positions along the longitudinal section using a color-difference meter $\left(\mathrm{CR}-200\right.$, Minolta, Tokyo). Hue angle $\left(0^{\circ}=\right.$ red-purple, $90^{\circ}$ = yellow, $180^{\circ}=$ blue-green, $270^{\circ}=$ blue $)$ calculations were made based on McGuire's method (1992). Fruit firmness was measured at the equator with a texture analyzer (TA-XT2; Charpa Techcenter, Bangkok, Thailand) and a $2 \mathrm{~mm}$ needle. Twelve fruit were used for these measurements.

StORAGE OF MANGoEs. After 'Nam Dok Mai' fruit was harvested at 42, 70, and 84DAFB, 80 fruit samples ( 8 per tree) were randomly divided into two groups. The first group was stored for $14 \mathrm{~d}$ at $75 \%$ $\mathrm{RH}$ at $20^{\circ} \mathrm{C}$. The second group was stored for $14 \mathrm{~d}$ at $90 \% \mathrm{RH}$ at $20{ }^{\circ} \mathrm{C}$. Twenty fruit for each RH were sampled for jasmonates, ACC, firmness, hue angle, weight loss, and $\mathrm{CO}_{2}$ analyses at 7 and $14 \mathrm{~d}$ in storage. 'Nang Klangwan' fruit was sampled at 42, 84, and 98 DAFB and examined similarly to 'Nam Dok Mai'.

$\mathrm{CO}_{2}$ AND ACC analysis. For $\mathrm{CO}_{2}$ analysis, 12 fruit selected randomly were each sealed in $650 \mathrm{~mL}$ glass vials for $3 \mathrm{~h}$ at 25 ${ }^{\circ} \mathrm{C}$ immediately after harvest. One $\mathrm{mL}$ headspace gas containing $\mathrm{CO}_{2}$ was analyzed by GLC (GC-380; GL Sciences, Tokyo). ACC concentrations in the skin and pulp (1 g dry weight) were analyzed by GLC using the method of Lizada and Yang (1979). The analysis conditions of GLC were as described (Kondo et al., 2002b).

Preparation of ( $\left.{ }^{(} \mathbf{H}_{2}\right)$-JA AND $\left({ }^{(} \mathbf{H}_{2}\right)$-MeJA. For use as the internal standards in a quantitative analysis of the endogenous JA and MeJA by gas chromatography-mass spectrometry-selected ion monitoring (GC-MS-SIM), the deuterium labeled JA $\left[\left({ }^{2} \mathrm{H}_{2}\right)-\mathrm{JA}\right.$ : $( \pm)-\left[9,10-{ }^{2} \mathrm{H}_{2}\right]$ jasmonic acid] and its methylester $\left[\left({ }^{2} \mathrm{H}_{2}\right)-\mathrm{MeJA}\right.$ : methyl $( \pm)-\left[9,10-{ }^{2} \mathrm{H}_{2}\right]$ jasmonate] were prepared from adipic acid via catalytic semi-deuteriogenation of methyl ( \pm )-9, 10-dehydrojasmonate, which was previously reported (Seto et al., 1996).

EXTRACTION AND ANALYSIS OF JASMONATES. Although plants contain both cis- and trans-JA and cis- and trans-MeJA, most of cis-isomers change to trans-isomers by isomerization in the extraction (Yamane, 1995). Thus, trans-JA and trans-MeJA were analyzed in this study. JAand MeJAextraction and quantification methods were based on those of Mueller et al. (1993) with some modifications. Fruit samples ( $1 \mathrm{~g}$ dry weight) were extracted with $1 \mu \mathrm{g}\left({ }^{2} \mathrm{H}_{2}\right)$ JA and $\left({ }^{2} \mathrm{H}_{2}\right)$ MeJA as the internal standards in a $20 \mathrm{~mL}$ saturated $\mathrm{NaCl}$ solution, $1 \mathrm{~mL} 1 \mathrm{M}$ citric acid and $50 \mathrm{~mL}$ diethyl ether containing $11.3 \mu \mathrm{M}$ butylated hydroxytoluene as the antioxidant. After centrifugation (10 $\mathrm{min}$ at $2000 \mathrm{~g}_{\mathrm{n}}$ ), the ether phase was removed, and the aqueous layer was extracted a second time with $50 \mathrm{~mL}$ diethyl ether containing $11.3 \mu \mathrm{M}$ butylated hydroxytoluene. Pooled etherextracts were dried with $\mathrm{N}_{2}$. The residue was then dis- solved in $200 \mu \mathrm{L}$ chloroform/diisopropylethylamine, 1:1 (v/v), and derivatized $60 \mathrm{~min}$ at $50{ }^{\circ} \mathrm{C}$ with $10 \mu \mathrm{L}$ pentafluorobenzyl (PFB) bromide. $\mathrm{N}_{2}$ was used again to concentrate the derivatized mixture.

The concentrated residue was dissolved into $5 \mathrm{~mL} n$-hexane and poured into a silica gel column $(5 \mathrm{~mm}$ i.d. $\times 14 \mathrm{~cm})[250$ mg of silica gel 60 (Merck KGaA, Darmstadt, Germany)]. The sample was eluted using $7 \mathrm{~mL} 2 n$-hexane : 1ether (by volume), dried with $\mathrm{N}_{2}$, redissolved in $1 \mathrm{~mL}$ methanol, and then applied to a SEP cartridge carbograph column [150 mg in $3 \mathrm{~mL}$ (GL Sciences, Tokyo)] to remove pigment substances such as chlorophyll. The sample was concentrated under $\mathrm{N}_{2}$, redissolved in $30 \mu \mathrm{L}$ methanol, and $1 \mu \mathrm{L}$ sample was analyzed by GC-MS [QP 5000; Shimadzu, Kyoto, Japan; column = CP-Sil 5 CB (Chrompack, Middelburg, Netherlands; $0.25 \mathrm{~mm}$ i.d. $\times 25 \mathrm{~m}, 0.25 \mu \mathrm{m}$ film thickness); linear He flow at $50.2 \mathrm{~cm} \cdot \mathrm{s}^{-1}$, column temperature step gradient, $60{ }^{\circ} \mathrm{C}$ for $2 \mathrm{~min}, 60$ to $270{ }^{\circ} \mathrm{C}$ at $10{ }^{\circ} \mathrm{C} \cdot \mathrm{min}^{-1}$, and $270{ }^{\circ} \mathrm{C}$ for $35 \mathrm{~min}$; electron potential, $70 \mathrm{eV}$ ]. Quantitative analyses were carried out using selected ion monitoring (SIM).

Retention times of the PFB derivatives are as follows: trans-JA, $19.65 \mathrm{~min} ;{ }^{2} \mathrm{H}_{2}$-JA, $19.65 \mathrm{~min}$, trans-MeJA, $14.25 \mathrm{~min} ;{ }^{2} \mathrm{H}_{2}$-MeJA, $14.25 \mathrm{~min}$. Ions were analyzed for JA/[ $\left.{ }^{2} \mathrm{H}_{2}\right]( \pm)-\mathrm{JA}$ as follows: $\mathrm{m} / \mathrm{z}$ $390,392,209$, and 211. In the original extract, JA concentration was determined from the ratio of peak areas for $m / z 390\left({ }^{2} \mathrm{H}_{0}\right) / 392$ $\left({ }^{2} \mathrm{H}_{2}\right)$. For MeJA/[ $\left.{ }^{2} \mathrm{H}_{2}\right]( \pm)-\mathrm{MeJA}$, with ions monitored as follows: $\mathrm{m} / \mathrm{z} 224,226,151$, and 153. MeJA concentration was determined from the ratio of peak areas for $m / z 224\left({ }^{2} \mathrm{H}_{0}\right) / 226\left({ }^{2} \mathrm{H}_{2}\right)$. The fragmentation patterns were compared to those [trans-PFB-JA: $\mathrm{m} / \mathrm{z}$ 390 (39) $\left(\mathrm{M}^{+}\right), 322$ (14), 209 (11), 191 (11), 181 (100), 141 (68); trans-PFB-MeJA: m/z 224 (24) (M+), 181 (88), 151 (39), 135 (43), 109 (29), 83 (100)] of the chemical standards to distinguish PFBjasmonates within the samples.

Statistical analysis. Data of Figs. 1 through 4 were subjected to analysis of variance procedures and means separated by LSD, $p$ $\leq 0.05$. Significant differences between treatments were identified using the Newmen-Keuls test, $p \leq 0.05$ in Figs. 5 through 7 and Table 1(SAS, Cary, N.C.).

\section{Results and Discussion}

Changes in jasmonates during fruit Development. In both cultivars, fruit weight increased sigmoidally until harvest (Fig. 1). Each

Fig. 1. Changes in fruit firmness, fruit weight, and skin hue angle in 'Nam Dok Mai' and 'Nang Klangwan' mangoes. Data are means of 12 fruit.

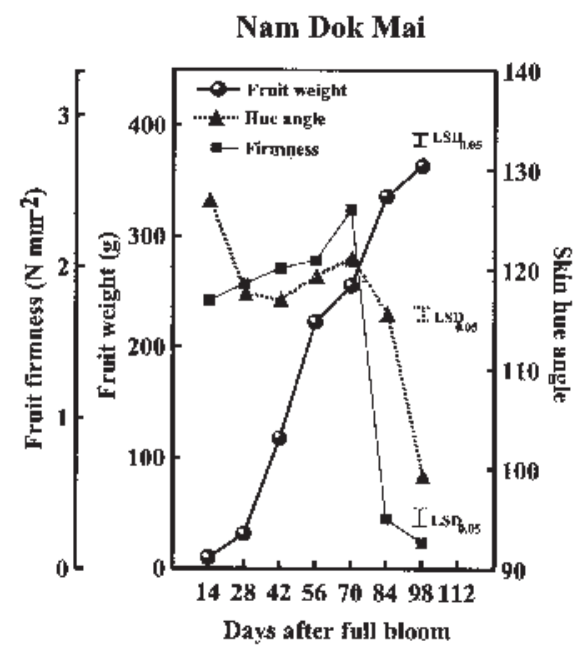



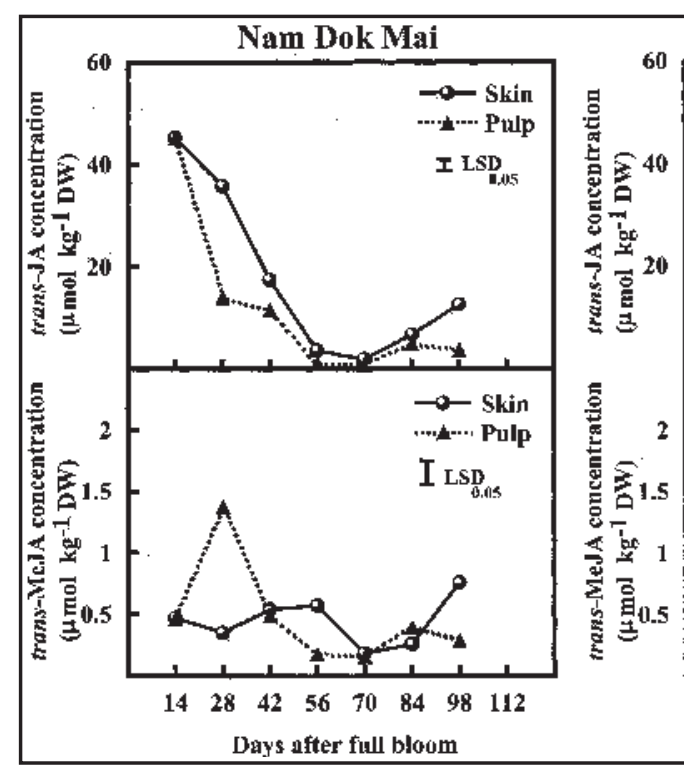

Fig. 2. Endogenous trans-JA and trans-MeJA concentrations in the skin and pulp of 'Nam Dok Mai' and 'Nang Klangwan' mangoes. Data are means of three replications.

fruit's firmness rose gradually until 70 DAFB, then fell markedly toward 98 DAFB in the early cultivar 'Nam Dok Mai' and toward 112 DAFB in the late-cultivar 'Nang Klangwan.' Hue angle on the skin decreased sharply after 84 DAFB in 'Nam Dok Mai' and after 98 DAFB in 'Nang Klangwan.' These results show that 70 to 84 DAFB in 'Nam Dok Mai' and 84 to 98 DAFB in 'Nang Klangwan' may be transition stages between development and ripening.

JA showed similar changes in the skin and pulp of both cultivars. In 'Nam Dok Mai,' JA concentration was the highest at 14 DAFB and then decreased gradually until 70 DAFB (Fig. 2). In 'Nang Klangwan,' JA concentration was also highest at 14 DAFB, but decreased sharply to 28 DAFB then leveled out until 84 DAFB where it increased sharply. At harvest, the JA concentration was higher in 'Nang Klangwan' (112 DAFB) than 'Nam Dok Mai' (98 DAFB). In 'Nam Dok Mai' pulp, MeJA reached its maximum at 28 DAFB, and then decreased toward 98 DAFB. Except for this, in the skin and pulp of both cultivars, MeJA concentrations were low, and no significant differences were observed during development. Our previous reports showed that the JA concentrations in apples and sweet cherries were the highest at the beginning of fruit development, and JA stimulated callus formation only on discs from pulp taken at the beginning of development (Kondo et al., 2001a, 2002a). Thus, the high JA concentrations at the beginning of mango fruit development may also influence cell division in the fruit.

Mangoes are classified as climacteric (Mitra and Baldwin, 2001). The changes in $\mathrm{CO}_{2}$ production in both cultivars during the latter part of the maturation period support this (Fig. 3). Furthermore, ACC concentrations in the skin and pulp of both cultivars increased toward harvest, and those in the pulp were higher than those in the skin. Especially in 'Nam Dok Mai,' ACC in the pulp increased rapidly after 56 DAFB, but that in the skin increased
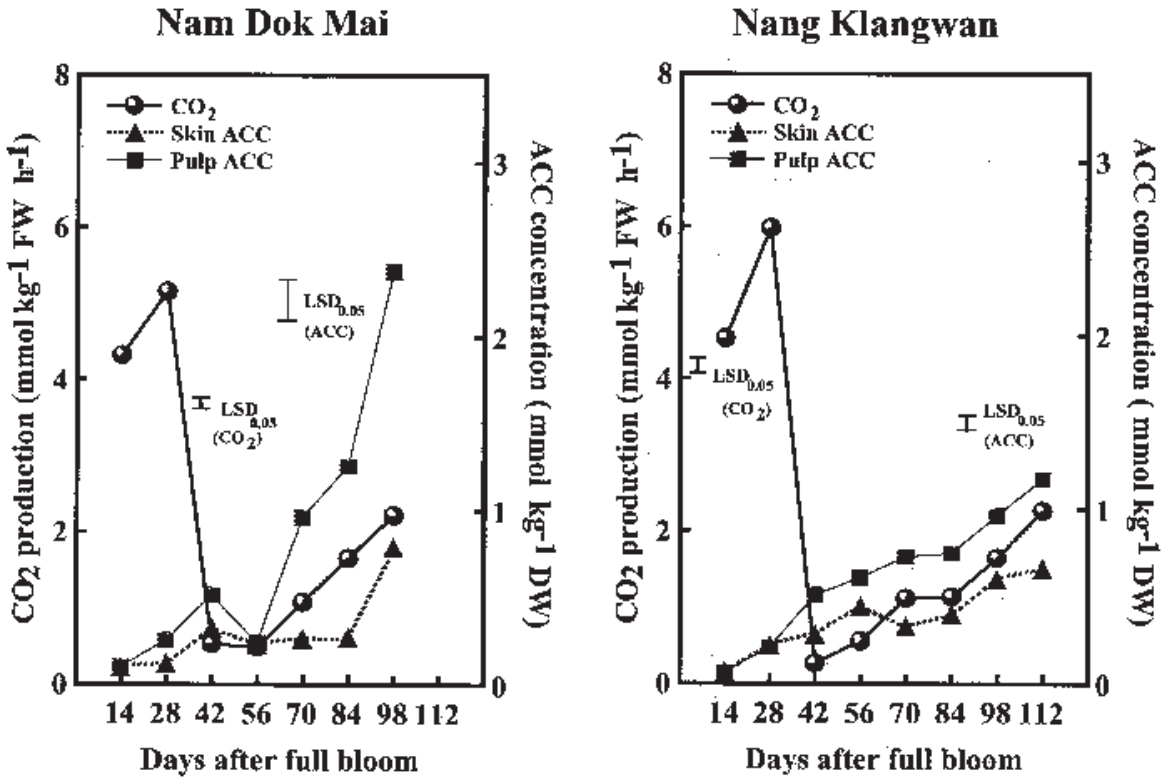

after 84DAFB. Similar trends in skin and pulpACC concentrations were measured in 'Nang Klangwan,' although the increase in pulp ACC was not as striking. The previous report on apples showed both ACC and ethylene concentrations were higher in the earlier cultivars, and ripening advanced rapidly after their appearance (Kondo et al., 1991). Generally, ethylene production changes in parallel with ACC concentrations (Hyodo et al., 1983). These facts suggest that in mangoes ripening begins earlier in pulp tissues than skin tissues.

JA increased at the ripening stage in climacteric fruit such as apples (Kondo et al., 2000), although it was not observed in nonclimacteric fruit such as grape berries (Kondo and Fukuda, 2001). Furthermore, JA treatment on apple fruit discs with skin significantly promoted anthocyanin accumulation (Kondo et al., 2001b). These reports support the hypothesis that increase of JA in mango fruit toward harvest may be related to fruit ripening. However, differing with ACC, JA concentrations in the skin were higher than those in the pulp. JA concentrations at the ripening stage of late-cultivar 'Nang Klangwan' were higher than those in early cultivar 'Nam Dok Mai.' JA treatment at the preclimacteric stage induced ACC and ethylene production, but treatments during and after climacteric stages inhibited ACC and ethylene production (Saniewski, 1987a, 1987b). This fact suggests that JA may influence the autocatalytic reaction of system 2 in the ethylene pathway. However, ACC concentrations in the skin and pulp of apples were higher in earlier cultivars (Kondo et al., 1991). In addition, aminoethoxyvinylglycine (AVG) which is an inhibitor of ACC synthase, did not influence anthocyanin biosynthesis in apple skins induced by JA application (Kondo et al., 2001b). Therefore, it was concluded that JA and ethylene influences on anthocyanin formation were independent. Their reports and our results that JA concentrations were high in late-cultivar 'Nang Klangwan' compared to early cultivar 'Nam Dok Mai,' suggest that both JA and ethylene may act independently, although they influence ripening

Fig. 3. $\mathrm{CO}_{2}$ production from fruit, skin and pulp ACC concentration in 'Nam Dok Mai' and 'Nang Klangwan' mangoes. Data are means of 12 fruit. 


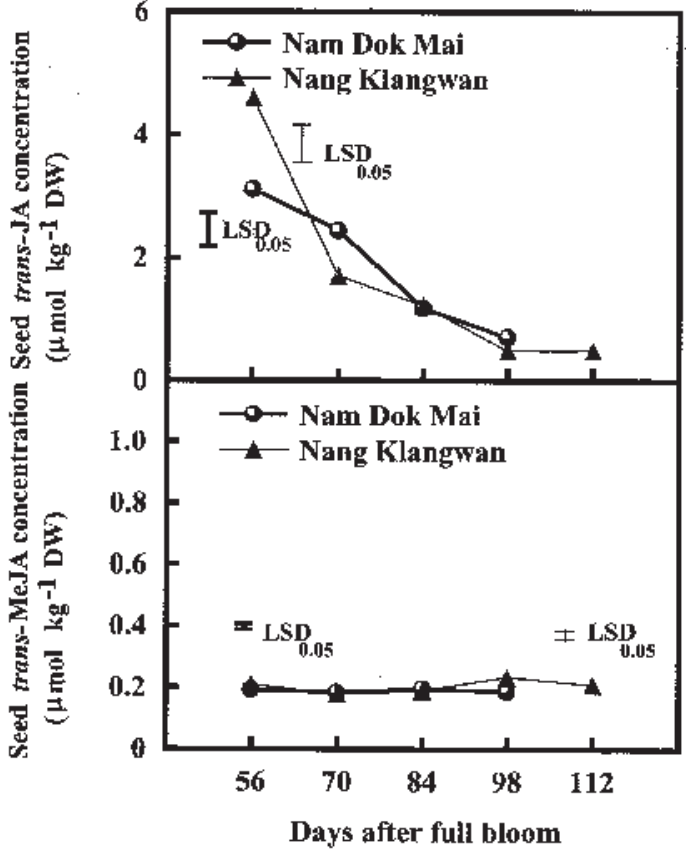

Fig. 4. Endogenous trans-JAand trans-MeJAconcentrations in the seeds of 'NamDok Mai' and 'Nang Klangwan' mangoes. Data are means of three replications. in mango fruit. Mango skin contains chlorophyll and carotenoids. Chlorophyll decreased with ripening, but the carotenoid levels increased (Mitra and Baldwin, 2001). MeJA treatment on apples significantly promoted degreening (Fan et al., 1998). Therefore, endogenous jasmonates may play a role in the loss of chlorophyll at the ripening stage of mangoes.

JAconcentrations in the seeds of both cultivars decreased toward harvest (Fig. 4). The concentrations of MeJA were lower than JA and did not show significant changes. On the contrary, JA and ABA concentrations in the seeds of apples and sweet cherries increased toward harvest (Kondo et al., 1999, 2000; Kondo and Tomiyama, 1998). The seeds of apples and sweet cherries require dormancy for germination, but tropical fruit seeds do not. Nonclimacteric mangosteen seeds (Garcinia mangostana L.) do not require dormancy, perhaps due to low ABA concentrations in the maturing seeds (Kondo et al., 2002b). These results suggest that, as well as ABA, the low endogenous JA concentrations in maturing seeds may be associated with the lack of dormancy in mango seeds.

Changes in Jasmonates during storage. From changes in fruit firmness (Fig. 1) and $\mathrm{CO}_{2}$ production (Fig. 3) in each cultivar, phenological stages were estimated. In 'Nam Dok Mai,' 42 DAFB was considered immature, 70 DAFB was considered preclimacteric, and 84 DAFB was considered climacteric. In 'Nang Klangwan,' 42 DAFB was immature, 84 DAFB was preclimacteric, and 98 DAFB was climacteric.

Table1. Fruit weight loss (FWL), firmness, hue angle, and $\mathrm{CO}_{2}$ production in mangoes harvested at different times $(\mathrm{HD}=$ harverst date $)$ and stored at different humidities ( $\mathrm{SC}=$ storage conditions). Data points within each sampling date [BS (before storage), 42, 70, 84, and 98 d after full bloom (DAFB)] in each item with different letters show significant differences as calculated by Newmen-Keuls test, $p \leq 0.05$.

\begin{tabular}{|c|c|c|c|c|c|c|}
\hline Cultivar & HD & $\mathrm{SC}$ & $\begin{array}{l}\text { FWL } \\
(\%)\end{array}$ & $\begin{array}{l}\text { Firmness } \\
\left(\mathrm{N} / \mathrm{mm}^{2}\right)\end{array}$ & $\begin{array}{c}\text { Hue } \\
\text { angle }\end{array}$ & $\begin{array}{c}\mathrm{CO}_{2} \\
\left(\mathrm{mmol} \cdot \mathrm{kg}^{-1} \cdot \mathrm{h}^{-1}\right)\end{array}$ \\
\hline \multirow{15}{*}{ Nam Dok Mai } & \multirow{5}{*}{42} & BS & & $1.57 \mathrm{a}$ & $117.1 \mathrm{a}$ & $0.53 \mathrm{a}$ \\
\hline & & $75 \%$ RH 7 d & $1.05 \mathrm{a}$ & $1.34 \mathrm{~b}$ & $118.1 \mathrm{a}$ & $0.20 \mathrm{~b}$ \\
\hline & & $75 \%$ RH $14 d$ & $1.03 \mathrm{a}$ & $0.80 \mathrm{~d}$ & $117.2 \mathrm{a}$ & $0.40 \mathrm{a}$ \\
\hline & & $90 \%$ RH 7 d & $0.71 \mathrm{~b}$ & $1.51 \mathrm{ab}$ & $119.0 \mathrm{a}$ & $0.31 \mathrm{~b}$ \\
\hline & & $90 \%$ RH 14 d & $0.78 \mathrm{~b}$ & $1.10 \mathrm{c}$ & $116.8 \mathrm{a}$ & $0.36 \mathrm{ab}$ \\
\hline & \multirow[t]{5}{*}{70} & BS & & $1.87 \mathrm{a}$ & $121.2 \mathrm{a}$ & $1.08 \mathrm{a}$ \\
\hline & & $75 \%$ RH 7 d & $1.53 \mathrm{c}$ & $1.70 \mathrm{~b}$ & $119.7 \mathrm{a}$ & $0.77 \mathrm{~b}$ \\
\hline & & $75 \%$ RH $14 d$ & $7.15 \mathrm{a}$ & $0.04 \mathrm{~d}$ & $111.7 \mathrm{~b}$ & $0.70 \mathrm{~b}$ \\
\hline & & $90 \%$ RH 7 d & $3.18 \mathrm{c}$ & $1.53 \mathrm{c}$ & $120.9 \mathrm{a}$ & $0.61 \mathrm{~b}$ \\
\hline & & $90 \%$ RH 14d & $5.45 \mathrm{~b}$ & $0.06 \mathrm{~d}$ & $109.0 \mathrm{~b}$ & $0.61 \mathrm{~b}$ \\
\hline & \multirow[t]{5}{*}{84} & BS & & $0.14 \mathrm{~b}$ & $115.6 \mathrm{~b}$ & $1.66 \mathrm{a}$ \\
\hline & & $75 \%$ RH 7 d & $11.88 \mathrm{a}$ & $0.15 \mathrm{~b}$ & $115.4 \mathrm{~b}$ & $0.84 \mathrm{~b}$ \\
\hline & & $75 \%$ RH $14 \mathrm{~d}$ & $13.43 \mathrm{a}$ & $0.08 \mathrm{c}$ & $122.7 \mathrm{a}$ & $0.32 \mathrm{c}$ \\
\hline & & $90 \%$ RH 7 d & $7.21 \mathrm{~b}$ & $0.22 \mathrm{a}$ & $111.2 \mathrm{bc}$ & $0.84 \mathrm{~b}$ \\
\hline & & $90 \%$ RH 14 d & $8.08 \mathrm{~b}$ & $0.04 \mathrm{c}$ & $106.4 \mathrm{c}$ & $0.38 \mathrm{c}$ \\
\hline \multirow[t]{15}{*}{ Nang Klangwan } & \multirow[t]{5}{*}{42} & BS & & $1.94 \mathrm{a}$ & $120.2 \mathrm{a}$ & $0.27 \mathrm{ab}$ \\
\hline & & $75 \%$ RH 7 d & $1.20 \mathrm{ab}$ & $1.50 \mathrm{~b}$ & $124.4 \mathrm{a}$ & $0.42 \mathrm{a}$ \\
\hline & & $75 \%$ RH $14 d$ & $1.30 \mathrm{a}$ & $0.82 \mathrm{c}$ & $120.6 \mathrm{a}$ & $0.21 \mathrm{~b}$ \\
\hline & & $90 \%$ RH 7 d & $0.99 \mathrm{c}$ & $1.63 \mathrm{~b}$ & $122.0 \mathrm{a}$ & $0.31 \mathrm{ab}$ \\
\hline & & $90 \%$ RH 14 d & $1.03 \mathrm{bc}$ & $0.75 \mathrm{c}$ & $120.2 \mathrm{a}$ & $0.29 \mathrm{ab}$ \\
\hline & \multirow[t]{5}{*}{84} & BS & & $1.23 \mathrm{c}$ & $127.9 \mathrm{a}$ & $1.14 \mathrm{a}$ \\
\hline & & $75 \%$ RH 7 d & $3.43 \mathrm{~b}$ & $1.57 \mathrm{~b}$ & $123.7 \mathrm{a}$ & $0.53 \mathrm{~b}$ \\
\hline & & $75 \%$ RH $14 \mathrm{~d}$ & $5.21 \mathrm{a}$ & $0.10 \mathrm{~d}$ & $119.6 \mathrm{~b}$ & $0.48 \mathrm{~b}$ \\
\hline & & $90 \%$ RH 7 d & $5.79 \mathrm{a}$ & $1.78 \mathrm{a}$ & $126.1 \mathrm{a}$ & $0.46 \mathrm{~b}$ \\
\hline & & $90 \%$ RH 14 d & $3.78 \mathrm{ab}$ & $0.14 \mathrm{~d}$ & $108.0 \mathrm{~b}$ & $0.51 \mathrm{~b}$ \\
\hline & \multirow[t]{5}{*}{98} & BS & & $0.32 \mathrm{a}$ & $128.8 \mathrm{a}$ & $1.65 \mathrm{a}$ \\
\hline & & $75 \%$ RH 7 d & $8.21 \mathrm{~b}$ & $0.08 \mathrm{~b}$ & $112.0 \mathrm{bc}$ & $0.65 \mathrm{~b}$ \\
\hline & & $75 \%$ RH $14 \mathrm{~d}$ & $12.12 \mathrm{a}$ & $0.08 \mathrm{~b}$ & $102.3 \mathrm{c}$ & $0.27 \mathrm{~b}$ \\
\hline & & $90 \%$ RH 7 d & $8.14 \mathrm{~b}$ & $0.12 \mathrm{~b}$ & $123.1 \mathrm{ab}$ & $0.52 \mathrm{~b}$ \\
\hline & & $90 \%$ RH 14 d & $12.17 \mathrm{a}$ & $0.09 \mathrm{~b}$ & $116.0 \mathrm{bc}$ & $0.33 \mathrm{~b}$ \\
\hline
\end{tabular}




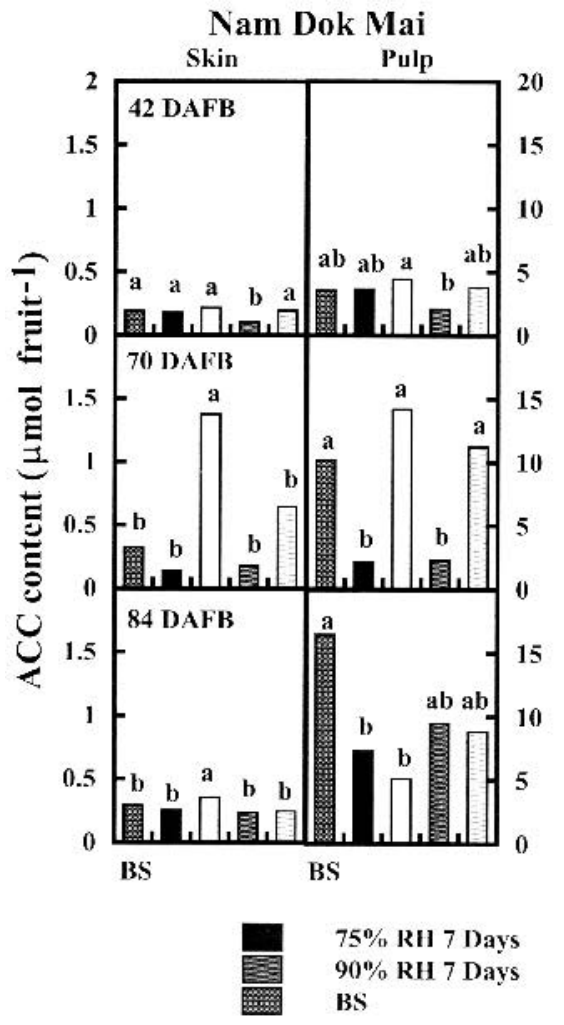

Firmness was the highest before storage and decreased with $\mathrm{d}$ in storage (Table 1). In both cultivars, except for the fruit harvested at $42 \mathrm{DAFB}$, hue angle of stored fruit became yellowish during $14 \mathrm{~d}$ in storage. $\mathrm{CO}_{2}$ production in both cultivars was the highest before storage and decreased during storage except for fruit harvested at 42 DAFB. $\mathrm{CO}_{2}$ production in the fruit harvested at $42 \mathrm{DAFB}$ decreased slightly during storage or leveled off. These results sug-

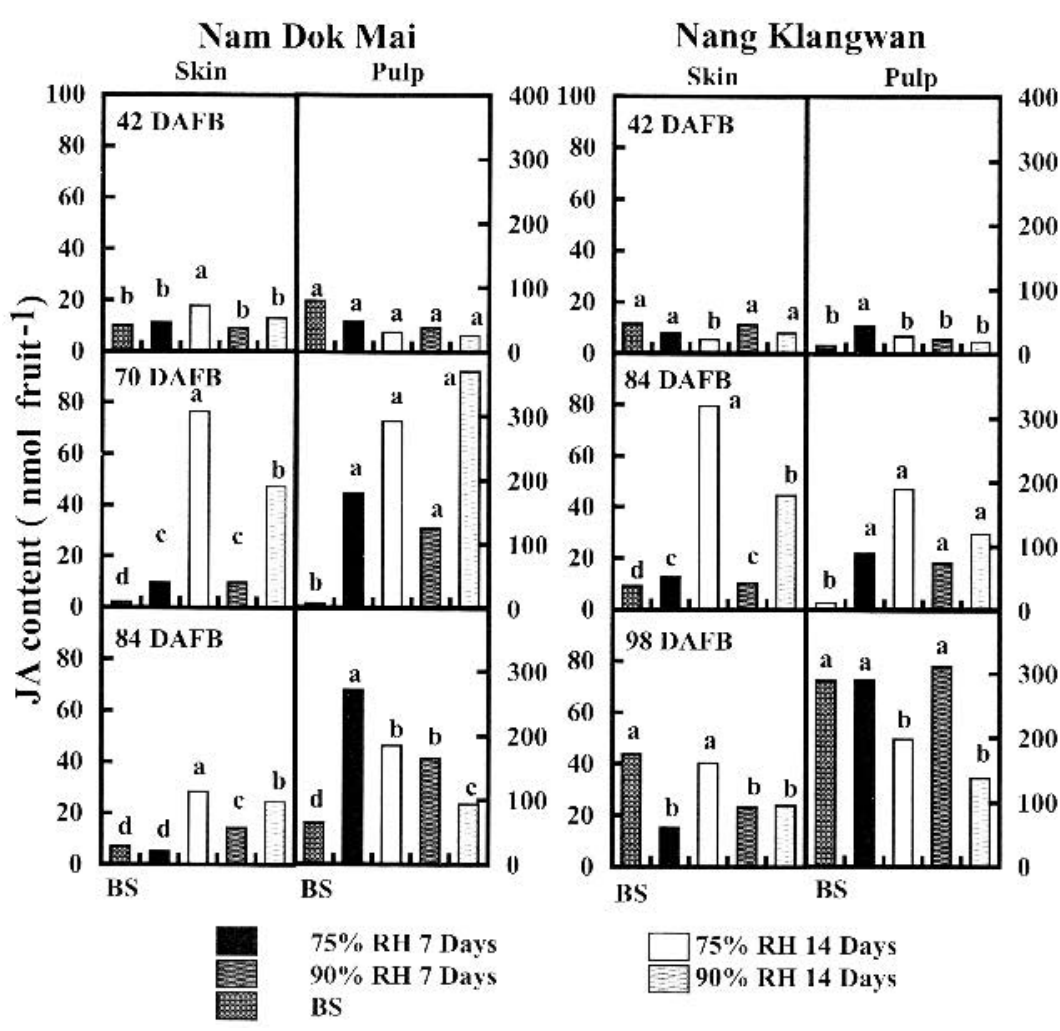

Fig. 5. ACC contents in the skin and pulp of 'Nam Dok Mai' and 'Nang Klangwan' mangoes stored for $7 \mathrm{~d}$ and $14 \mathrm{~d}$ at $75 \%$ relative humidity (RH) at $20{ }^{\circ} \mathrm{C}$ or $90 \% \mathrm{RH}$ at $20^{\circ} \mathrm{C}$. Data are means of three replications. Data points within each sampling date [BS (before storage), 42, 70, 84, and $98 \mathrm{~d}$ after full bloom (DAFB)] in the skin and pulp with different letters show significant differences as calculated by Newmen-Keuls test, $p \leq 0.05$.

gest that fruit ripening occurred during storage, then reached the postclimacteric stage in fruit harvested 70 and 84 DAFB for 'Nam Dok Mai', and 84 and 98 DAFB for 'Nang Klangwan'. In contrast, it is assumed that ripening failed to occur in fruit harvested at 42 DAFB. This conclusion is also supported by the fact that a large difference in $\mathrm{CO}_{2}$ production from 42 to 56 DAFB was not observed during fruit development on the tree (Fig. 3). ACC contents in the skin of 'Nam Dok Mai' fruit stored at 75\% RH for $14 \mathrm{~d}$ (75\% RH:14 d) after harvest at 70 and 84 DAFB increased compared to before storage (Fig. 5). However, other clear trends were not observed between storage and ACC. In 'Nam Dok Mai,' storage under differing humidities caused a significant difference in fruit weight loss. That is, the weight loss of fruit stored at $75 \%$ RH was greater than that of fruit stored at $90 \% \mathrm{RH}$ (Table 1). The 'Nam Dok Mai' fruit at $75 \%$ RH: $14 \mathrm{~d}$ at 70 and 84 DAFB whose ACC contents were high had significant weight loss. Although there appears to be a correlation between increased ACC content and increased weight loss, data are insufficient to determine cause and effect.

Large changes in JA levels during storage were found. In the skin and pulp of 'Nam Dok Mai' harvested at 70 and 84DAFB, and 'Nang Klangwan' harvested at 84 DAFB, JA levels significantly increased compared to before storage (Fig. 6). MeJA levels also increased in the skin and pulp of 'Nam Dok Mai' fruit harvested at $70 \mathrm{DAFB}$ and in the skin of fruit stored at $75 \% \mathrm{RH}$ and $90 \% \mathrm{RH}$ after harvest at 84 DAFB (Fig. 7). In both cultivars, JA increased after the preclimacteric stage (Fig. 2) and ACC increased toward harvest (Fig. 3). This suggests that ACC and JA are associated with mango fruit ripening and/or senescence. On the whole, however, a marked increase of ACC was not observed in fruit stored after harvest at 70 and 84 DAFB for 'Nam Dok Mai', and after harvest at 84 DAFB and 98 DAFB for 'Nang Klangwan'. These observations suggest that fruit was in the postclimacteric stage after $7 \mathrm{~d}$ and $14 \mathrm{~d}$ in storage as shown from changes of $\mathrm{CO}_{2}$ production in Table 1. In contrast, JA levels in fruit harvested after the preclimacteric stage of both cultivars significantly increased during storage. This fact suggests that JA may promote senescence of mango fruit separately from ethylene. Although the changes of JA in 'Nang Klangwan' fruit at $98 \mathrm{DAFB}$ were not as apparent, in the skin at $75 \%$ RH: $14 \mathrm{~d}$ at 42,70 , and 84 DAFB in 'Nam Dok Mai' and in the skin at 75\% RH: $14 \mathrm{~d}$ at 84 DAFB in 'Nang Klangwan,' JA levels were higher than other fruit at same time. The degree of weight loss was

Fig. 6. Endogenous trans-JA contents in the skin and pulp of 'Nam Dok Mai' and 'Nang Klangwan' mangoes stored for $7 \mathrm{~d}$ and $14 \mathrm{~d}$ at $75 \%$ relative humidity (RH) at $20^{\circ} \mathrm{C}$ or $90 \% \mathrm{RH}$ at $20{ }^{\circ} \mathrm{C}$. Data are means of three replications. Data points within each sampling date [BS (before storage), 42, 70, 84, and $98 \mathrm{~d}$ after full bloom (DAFB)] in the skin and pulp with different letters show significant differences as calculated by Newmen-Keuls test, $p \leq 0.05$. 

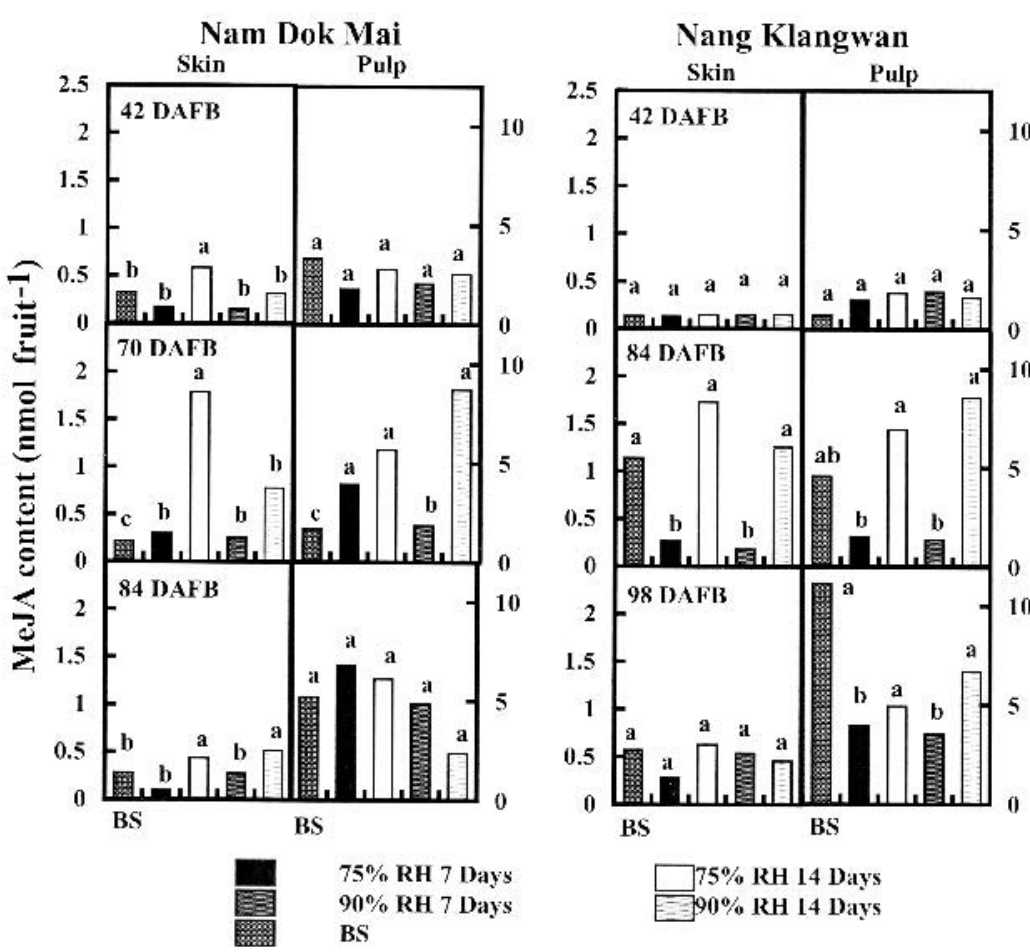

Fig. 7. Endogenous trans-MeJA contents in the skin and pulp of 'Nam Dok Mai' and 'Nang Klangwan' mangoes stored for $7 \mathrm{~d}$ and $14 \mathrm{~d}$ at $75 \%$ relative humidity (RH) at $20{ }^{\circ} \mathrm{C}$ or $90 \% \mathrm{RH}$ at $20{ }^{\circ} \mathrm{C}$. Data are means of three replications. Data points within each sampling date [BS (before storage), 42, 70, 84, and $98 \mathrm{~d}$ after full bloom (DAFB)] in the skin and pulp with different letters show significant differences as calculated by Newmen-Keuls test, $p \leq 0.05$.

also great in these fruit. These results suggest that the increase of JA levels in stored fruit may be connected with senescence caused by moisture loss. The results of our study show that JA may influence the senescence more strongly than ACC in mangoes.

In summary, the changes in JA concentrations in the skin and pulp suggest that jasmonates may be associated with the cell division and ripening stages of mango fruit. The different patterns of jasmonate and ACC concentration during fruit development indicates they may act independently of one another to induce ripening. Senescence is associated with fresh weight loss and may also be correlated with increased JA levels.

\section{Literature Cited}

Blanpied, G. D. and V. A. Blak. 1976. Relationship between ethylene level and varietal flavor in 'Delicious' apples. HortScience 11:596-597.

Fan, X., J.P. Mattheis, and J.K. Fellman. 1998. Responses of apples to postharvest jasmonate treatments. J. Amer. Soc. Hort. Sci. 123:421-425.

Hyodo, H., K. Tanaka, and K. Watanabe. 1983. Wound-induced ethylene production and 1-aminocyclopropane-1-carboxylic acid synthase in mesocarp tissue of winter squash fruit. Plant Cell Physiol. 24:963-969.

Koda, Y., E.A. Omer, T. Yoshihara, H. Shibata, S. Sakamura, and Y. Okazawa. 1988. Isolation of a specific potato tuber-inducing substance from potato leaves. Plant Cell Physiol. 29:1047-1051.

Kondo, S. and K. Fukuda. 2001. Changes of jasmonates in grape berries and their possible roles in fruit development. Scientia Hort. 91:275-288.

Kondo, S., K. Inoue, and M. Tamaki. 1999. Changes of abscisic acid and its metabolite during development of apple fruit. J. Hort. Sci. Biotechnol. 74:762-767.
Kondo, S., M. Motoyama, H. Michiyama, and M. Kim. 2002a. Roles of jasmonic acid in the development of sweet cherries as measured from fruit or disc samples. Plant Growth Regulat. $37: 37-44$.

Kondo, S., W. Ponrod, S. Kanlayanarat, and N. Hirai. 2002b. Abscisic acid metabolism during fruit development and maturation of mangosteens. J. Amer. Soc. Hort. Sci. 127:737-741.

Kondo, S. and A. Tomiyama. 1998. Changes of free and conjugated ABA in the fruit of 'Satohnishiki' sweet cherry and the ABA metabolism after application of (s)-(+)-ABA. J. Hort. Sci. Biotechnol. 73:467-472.

Kondo, S., A. Tomiyama, and H. Seto. 2000. Changes of endogenous jasmonic acid and methyl jasmonate in apples and sweet cherries during fruit development. J. Amer. Soc. Hort. Sci. 125:282-287.

Kondo, S., N. Tsukada, and Y. Niimi. 2001a. Stimulative effect of jasmonic acid on callus formation in apple fruit. J. Jpn. Soc. Hort. Sci. 70:229-231.

Kondo, S., N. Tsukada, Y. Niimi, and H. Seto. 2001b. Interactions between jasmonates and abscisic acid in apple fruit, and stimulative effect of jasmonates on anthocyanin accumulation. J. Jpn. Soc. Hort. Sci. 70:546-552.

Kondo, S., J. Uthaibutra, and H. Gemma. 1991. Comparison of 1-aminocyclopropane-1-carboxylic acid, abscisic acid and anthocyanin content of some apple cultivars during fruit growth and maturation. J. Jpn. Soc. Hort. Sci. 60: 505-511.

Lizada, M.C.C. and S.F. Yang. 1979. A simple and sensitive assay for 1-aminocyclopropane-1-carboxylic acid. Anal. Biochem. 100:140-145.

McGuire, R. G. 1992. Reporting of objective color measurements. HortScience 27:1254-1255.

Mitra S.K. and E.A. Baldwin. 2001. Mango, p. 85-122. In: S. Mitra (ed.). Postharvest physiology and storage of tropical and subtropical fruits. CAB Intl, Wallinford, U.K.

Mueller, M.J., W. Brodschelm,E. Spannagl and M.H.Zenk. 1993. Signaling in the elicitation process is mediated through the octadecanoid pathway leading to jasmonic acid. Proc. Natl. Acad. Sci. USA 90:7490-7494.

Nojiri, H., H. Yamane, H. Seto, I. Yamaguchi, N. Murofushi, T. Yoshihara, and H. Shibaoka. 1992. Qualitative and quantitative analysis of endogenous jasmonic acid in bulbing and non-bulbing onion plants. Plant Cell Physiol. 33:1225-1231.

Saniewski, M., J. Czapski, J., J. Nowacki, and E. Lange. 1987a. The effect of methyl jasmonate on ethylene and 1-aminocyclopropane-1-carboxylic acid production in apple fruits. Biol. Plant. 29:199-203.

Saniewski, M., J. Nowacki, and J. Czapski. 1987b. The effect of methyl jasmonate on ethylene production and ethylene-forming enzyme activity in tomatoes. J. Plant Physiol. 129:175-180.

Seto, H., S. Fujioka, H. Fujisawa, K. Goto, H. Nojiri, H. Yamane, and S. Yoshida. 1996. Preparation of $( \pm)-2-\left(2,3-2 \mathrm{H}_{2}\right)$ jasmonic acid and its methyl ester, methyl $( \pm)-2-\left(2,3-2 \mathrm{H}_{2}\right)$ jasmonate. Biosci. Biotechnol. Biochem. 60:1709-1711.

Takeuchi, Y. and Y. Kamuro. 1997. Physiology and present situation of practical use of brassinosteroid and jasmonoid compounds. Chem. Regulat. Plants 32:74-86.

Tamari, G.,A. Borochov, R. Atzorn, and D. Weiss. 1995. Methyl jasmonate induces pigmentation and flavonoid gene expression in petunia corollas: a possible role in wound response. Physiol. Plant. 94:45-50.

Tsuda, T., K. Chachin, and Y. Ueda. 1999. Studies on keeping quality of imported 'Carabao' mango fruit from the Philippines. J. Jpn. Soc. Hort. Sci. 68:669-674.

Ueda, J. 1991. Jasmonic acid and its related compounds: The history of discovery, chemistry and physiology. Chem. Regulat. Plants 26:173-189. Yamane, H. 1995. Biosynthesis of jasmonic acid and its regulation. Chem. Regulat. Plants 39:141-143. 